\title{
Nitrogen fertilization on ornamental ginger under fertigation in protected cultivation
}

\author{
Douglas José Marques ${ }^{1} \mathbb{D}$; Hudson C Bianchini ${ }^{1} \mathbb{D}$; Aloisio P de Souza ${ }^{1} \mathbb{D}$ \\ 'UNIFENAS, Alfenas-MG, Brazil; douglas.marques@unifenas.br; hudson.bianchini@unifenas.br; aloisioportosouza@uol.com.br
}

\begin{abstract}
Tropical floriculture has increased significantly in the last decade due to a growing worldwide market trend of consuming exotic, colorful, beautiful and durable flowers. Among the tropical floriculture products, ornamental gingers, species belonging to the families Zingiberaceae and Costaceae, have high potential for ornamental use, both for landscaping, for cut and potted flower and foliage. However, little information can be found in literature when it comes to crop fertilization, mainly concerning nitrogen fertilization, quite important to tropical soils which are poor in organic matter resource. Thus, this study aimed to evaluate application of nitrogen doses, using fertigation for growing ornamental ginger under protected cultivation. The experiment was carried out from 2012 to 2016, using seedlings produced in vitro multiplication. Plantlets remained for a period of acclimatization in a nursery and, then were planted in pits spaced $1 \times 1 \mathrm{~m}$ in a greenhouse. The agronomic parameters and recommendation of nitrogen using SPAD were evaluated from the beginning 2013 until 2016. The experimental arrangement was in randomized blocks with five nitrogen doses $\left(0,100,200,300\right.$ and $\left.400 \mathrm{~kg} \mathrm{ha}^{-1}\right)$ and 4 replicates. The increase of nitrogen doses, up to $400 \mathrm{~kg} \mathrm{ha}^{-1}$ via fertigation, produces $77100-\mathrm{cm}-$ height commercial flowers/tussock/year, favoring the commercial production and standardization of ornamental ginger.
\end{abstract}

Keywords: Zingiber spectabile, SPAD index, tropical floriculture.

\begin{abstract}
RESUMO
Adubação nitrogenada na produção do gengibre ornamental fertirrigado em cultivo protegido

A floricultura tropical tem se expandido bastante na última década devido a uma crescente tendência do mercado mundial em consumir flores exóticas, coloridas, belas e duráveis. Dentre os produtos da floricultura tropical, os gengibres ornamentais, assim descritas as espécies pertencentes às famílias Zingiberaceae e Costaceae, têm alto potencial de uso ornamental, tanto para paisagismo, como para flor e folhagem de corte e envasadas. No entanto, quando se pesquisa sobre a adubação dessa cultura, constata-se uma carência de informações atualizadas, principalmente no que se refere à adubação nitrogenada, tão importante para os solos tropicais, que possuem pouca reserva de matéria orgânica. Sendo assim, a pesquisa teve como objetivo avaliar a aplicação de doses de nitrogênio, utilizando o sistema de fertirrigação em gengibre ornamental, sob cultivo protegido. $\mathrm{O}$ experimento foi conduzido dos anos 2012 a 2016, utilizando mudas produzidas por meio da multiplicação in vitro, que permaneceram por um período de aclimatação no viveiro e, posteriormente, foram plantadas em covas com espaçamento de $1 \times 1 \mathrm{~m}$ em casa de vegetação. Os parâmetros agronômicos e indicação de nitrogênio usando o SPAD foram avaliados a partir do início do ano de 2013, estendendo-se até 2016. Foi utilizado o arranjo experimental em blocos casualizados, com cinco doses de nitrogênio $\left(0,100,200,300\right.$ e $\left.400 \mathrm{~kg} \mathrm{ha}^{-1}\right)$ e 4 repetições. Conclui-se com este trabalho que o aumento das doses de nitrogênio até $400 \mathrm{~kg} \mathrm{ha}^{-1}$ via fertirrigação produz 77 flores comerciais por touceira/ano com $100 \mathrm{~cm}$ de altura, favorecendo a produção comercial e a padronização do gengibre ornamental.
\end{abstract}

Palavras chave: Zingiber spectabile, índice SPAD, floricultura tropical.

\section{Received on May 7, 2018; accepted on February 25, 2019}

$\mathrm{F}$ lower production chain totaled over 10 billion Reais per year, collecting approximately 2.5 billion Reais in taxes, even considering that the per capita consumption of flowers in the country is very low and that more than half of this flower production has no quality standard.

Considering this and other information found, we could infer that many opportunities for improvement and expansion in this sector can be noticed. Commercial exploitation of flowers has increased in the last years, mainly, in relation to evolution of socioeconomic indicators, improvement in distribution system and expansion of flower and plant consumption as exponent elements of life quality, wellbeing and rapprochement of nature (Ibraflor, 2015).

According to Sebrae (2015), considering commercial values, the states of SP, MG and SC represent approximately $80 \%$ of revenue from flowers and cut foliage, $80 \%$ of revenue from flowers and pot plants and $60 \%$ of revenue from ornamental plants and landscaping, except grass.

In the competitive ornamental flower sector, traits of tropical flowers favor their commercialization: beauty, exoticism, variety of colors and shapes, resistance to transport and post-harvest durability. The demand for these ornamental plants has increased 
significantly in the national market (Luz et al., 2005).

Zingiberaceae family consists of 53 genera and over 1,200 species from Asian tropical regions, from tropical Africa up to South and Central America (Albuquerque \& Neves, 2004). Ornamental ginger belongs to Zingiberaceae family; the plant is herbaceous, rhizomatous, perennial, robust, whose stems reach up to $2.5 \mathrm{~m}$ high, elongated, velvety and lanceolate leaves at the bottom. The plants require soils rich in organic matter for development (Terao et al., 2005). Terminal inflorescences may present a diameter up to $12.0 \mathrm{~cm}$ : they are connected to a 0.30 to 0.80 -m upright stem, present a cylindrical shape with bracts which emerge during warmer months (November to April). The inflorescences are bright yellow turning reddish with age. According to Lamas (2002), ornamental ginger transplant is easy, showing vigorous growth, persistent to handling and of great durability. Productivity may reach 100 flowers/tussock/year. All parts of the plant exhale the characteristic ginger aroma (Bezerra \& Loges, 2005).

Tropical plant fertilization still needs further studies, since little information can be found in literature. Nitrogen is the nutrient which is the most required by plants, being considered the most limiting for growth. Nitrogen is absorbed by the plant in the form of nitrate $\left(\mathrm{NO}_{3}^{-}\right)$and/or ammonium $\left(\mathrm{NH}_{4}^{+}\right)$. When it is absorbed, nitrogen is reduced to ammoniacal form for the formation of different amino acids (Wang et al., 2018). Proteins, chlorophyll molecule, nucleic acids and several other compounds have nitrogen in its composition, acting in biochemical and physiological processes (Fageria, 2014).

In soil, nitrogen is present both in organic and inorganic form, mainly in organic form (approximately 98\%) (Moreira et al., 2013); however, organic compounds need to be degraded by microorganisms so that $\mathrm{N}$ can be assimilated by plants; this process is known as mineralization. Organic N mineralization rate is too variable and, generally, does not meet plant nutrient demand.

Epstein \& Bloom (2004) highlight that $\mathrm{N}$ deficiency is the most limiting factor in plant development, being the main symptoms generalized leaf chlorosis and reduced growth. Chlorosis caused by lack of $\mathrm{N}$ occurs mainly in older leaves, due to high phloem mobility of this nutrient; other symptoms of $\mathrm{N}$ deficiency are: dormancy of lateral gems, reduction of tillers, smaller leaves and low chlorophyll content. In $\mathrm{N}$-deficient plants, growth reduction is also noticed, flower openings delayed for 3 to 5 weeks and diameter is halved, when compared to flowers of normal plants; petals were normal, though (Wisnubroto et al., 2017).

Tropical flower production, under protected environment, is still growing in Brazil, since few studies on positive effect of this technology can be found. In ornamental plant production chain, companies commercializing polymers are essential parts of this chain, favoring an improvement of conditions for higher-quality plant production. This technology is used, mainly, by producers with higher technological level, which includes fertigation use.

The revenues of plastic and plastic house companies and other agrotextiles earned, approximately, $\mathrm{R} \$ 118$ millions in 2014, which is about $9 \%$ of the total revenue of ornamental plants' sector, considering that the companies of irrigation and fertigation equipment earned R \$ 82 million, which is about 6\% of revenue (Ibraflor, 2015).

Considering these pieces of information as well as other findings, we could verify the need to improve and expand management of ornamental plants in tropical weather in a greenhouse, aiming its expansion and creating information on proper nitrogen fertilization via fertigation. This is a crucial condition to increase the production of ornamental ginger, improve its quality and reduce production costs.

Thus, this study aimed to evaluate application of different nitrogen doses, using fertigation on ornamental ginger, under protected environment.

\section{MATERIAL AND METHODS}

The experiment was carried out from August, 2012 to December, 2016, at Setor de Olericultura in a protected cultivation area, in a greenhouse, archdetached type, 225 meters (9-meter width $\mathrm{x} 25$-m length) and $4.0 \mathrm{~m}$ ceiling height, covered with a $150 \mu \mathrm{m}$ diffusing agro film. The local climate is tropical mesothermic; summer and spring are the warmest seasons, with maximum temperature ranging from 28 to $30^{\circ} \mathrm{C}$; October and November are the warmest months reaching up 36 to $37^{\circ} \mathrm{C}$ and minimum of 9 to $10^{\circ} \mathrm{C}$, according to Köppen's international classification (Cunha et al., 1999).

Crop implantation was in August, 2012. The authors used seedlings produced in vitro multiplication, which remained for a period of acclimatization in polyethylene bags kept in commercial substrate Bioplant ${ }^{\circledR}$ composed of pinus and vermiculite, in the proportion $1: 1(\mathrm{v} / \mathrm{v})$ for about 30 days. Before pit preparation prior to planting, soil chemical analysis was performed according to the methodology of Raij et al. (2001), in the layer from 0 to 20 $\mathrm{cm}$. The typic distrophic Red Latosol presented the following chemical and granulometric characterization (Camargo et al., 2009): $\mathrm{pH}$ in $\mathrm{H}_{2} \mathrm{O}=$ 5.5; M.O. $=0.7 \mathrm{~g} \mathrm{dm}^{-3}$; P-Mehlich $=6$ $\mathrm{mg} \mathrm{dm}{ }^{-3} ; \mathrm{K}=0.7 \mathrm{mmol}_{\mathrm{c}} \mathrm{dm}^{-3} ; \mathrm{Ca}^{2+}=9$ $\mathrm{mmol}_{\mathrm{c}} \mathrm{dm}^{-3} ; \mathrm{Mg}^{2+}=4 \mathrm{mmol}_{\mathrm{c}} \mathrm{dm}^{-3} ; \mathrm{Al}^{3+}$ $=2 \mathrm{mmol}_{\mathrm{c}} \mathrm{dm}^{-3} ; \mathrm{H}+\mathrm{Al}=40 \mathrm{mmol}_{\mathrm{c}} \mathrm{dm}^{-3}$; $\mathrm{SB}=14 \mathrm{mmol}_{\mathrm{c}} \mathrm{dm}^{-3}$; CTC potential (T) $=54 \mathrm{mmol}_{\mathrm{c}} \mathrm{dm}^{-3}$; CTC effective (t) $=16 \mathrm{mmol}_{\mathrm{c}} \mathrm{dm}^{-3} ; \mathrm{V}=26 \% ; \mathrm{m}=$ $12 \%$; P-remaining $=10 \mathrm{mg} \mathrm{L}^{-1}$; clay $=420 \mathrm{~g} \mathrm{~kg}^{-1}$; sand $=430 \mathrm{~g} \mathrm{~kg}^{-1}$; silt $=150 \mathrm{~g} \mathrm{~kg}^{-1}$. After acclimatization period, the seedlings were transplanted into planting pits, spaced $1.0 \times 1.0 \mathrm{~m}$ in double row. Planting fertilization consisted of $300 \mathrm{~kg} \mathrm{P}_{2} \mathrm{O}_{5}$ and $70 \mathrm{~kg} \mathrm{~K}_{2} \mathrm{O}$ ha $^{-1}$, in the form of triple superphosphate $\left(41 \% \mathrm{P}_{2} \mathrm{O}_{5}\right.$ and $\left.14 \% \mathrm{Ca}\right)$ and potassium chloride $\left(60 \% \mathrm{~K}_{2} \mathrm{O}\right)$, respectively (Lamas, 2002). The rest of potassium and nitrogen fertilization was splitted in 10 applications in each year, via fertigation, using urea PA $(46 \% \mathrm{~N})$ 
and potassium chloride $\mathrm{PA}\left(60 \% \mathrm{~K}_{2} \mathrm{O}\right)$. We used by-pass fertigation system; $\mathrm{N}$ doses of treatments were applied via irrigation water in three different stages. Irrigation management was carried out, considering soil water retention characteristic curve and tensiometer readings installed $0.20-\mathrm{m}$ depth. In order to establish different treatments, irrigation was calculated based on humidity of field capacity, according to recommended for the crop (Guerra, 1994). During the first stage, irrigation system was triggered for a period corresponding to a quarter of the calculated irrigation time, to hydraulically balance the irrigation units as a whole. In the second stage, fertilizers were injected in irrigation system. In the third stage, system continued to function, aiming to complement the total irrigation time, to favor the transport of fertilizers from the surface to deeper layers of the soil. Urea was applied alternately by applying urea on one day and potassium chloride the other day. The quantities applied per irrigation unit were calculated based on irrigation time. The authors used a 500-L-capacity asbestos fiber tank in order to store the solution, being connected to two points of irrigation system. The water would solubilize and drag fertilizers as passed through the tank.

The experimental design was randomized blocks. The treatments consisted of five doses of nitrogen $(\mathrm{N})$, using urea as a source $(46 \% \mathrm{~N})$, consisting of $0 ; 100 ; 200 ; 300$ and 400 $\mathrm{kg} \mathrm{ha}{ }^{-1} \mathrm{~N}$, being the dose of $200 \mathrm{~kg} \mathrm{ha}^{-1}$ nitrogen commonly recommended for ornamental ginger, according to Lamas (2002). Each plot consisted of two lines, 6 plants in each line and 4 replicates, using a 2-plant border.

During the experiment, the authors performed conduction, management, fertilization and treatment implantation, production and collection of inflorescences, from November to April, from 2013 to 2016. Number of tillers was counted monthly. During the productive stage, harvest was performed weekly; we counted the discarded, unripe, green and commercial stems, according to Velling-Holambra's classification (2018). Inflorescence and stem height were quantified with the aid of a graduated scale $(\mathrm{cm})$. A caliper was used in order to obtain the diameter in the base, in the middle and the top of the inflorescence $(\mathrm{cm})$. Figure 1 shows the image during the experiment.

SPAD index was determined on physiological active leaves, excluding low leaves and the ones above the fully expanded leaves from the apex. Measurements were done between 7 and 9 a.m., using portable SPAD-502 chlorophyll meter (Minolta Camera Co. Ltda.). Five measurements were done in central region of leaf blade in each plant of the useful plot, totalizing 30 measurements per plot. The average was used to represent treatments, at the beginning and at the end of the experiment.

Results found in different evaluations were submitted to variance analysis. To evaluate the averages Scott-Knott test or t-test was applied, according to theories recommended by Steel et al. (2006). Standard deviations were calculated and regression estimators were applied (Pearson or Spearman), with the aid of SISVAR software (Ferreira, 2011).

\section{RESULTS AND DISCUSSION}

Number of tillers/tussock/year (Table 1) was greater for doses of 300 and $400 \mathrm{~kg} \mathrm{ha}^{-1} \mathrm{~N}$ (100 and 94 tillers, respectively). These doses are higher than the recommended for this crop, which is $200 \mathrm{~kg} \mathrm{ha}^{-1} \mathrm{~N}$ (Lamas, 2002). Number of tillers is important for the crop, since the greater the quantity, the greater is the leaf production, the greater is the production of energy via photosynthesis and the greater is absorption of water and nutrients

Table 1. Number of tillers/tussock/year in relation to $\mathrm{N}$ doses applied via fertigation in ornamental ginger crop. Alfenas, UNIFENAS, 2012-2016.

\begin{tabular}{lc}
\hline $\begin{array}{l}\text { N doses (kg } \\
\left.\mathbf{h a}^{-1}\right)\end{array}$ & $\begin{array}{c}\text { Number of } \\
\text { tillers }\end{array}$ \\
\hline 0 & $67 \mathrm{~d}$ \\
100 & $78 \mathrm{c}$ \\
200 & $83 \mathrm{~b}$ \\
300 & $100 \mathrm{a}$ \\
400 & $94 \mathrm{a}$ \\
\hline
\end{tabular}

Averages followed by same letters in the column do not differ statistically by ScottKnott test, 5\% significance $(\mathrm{P} \leq 0,05)$.

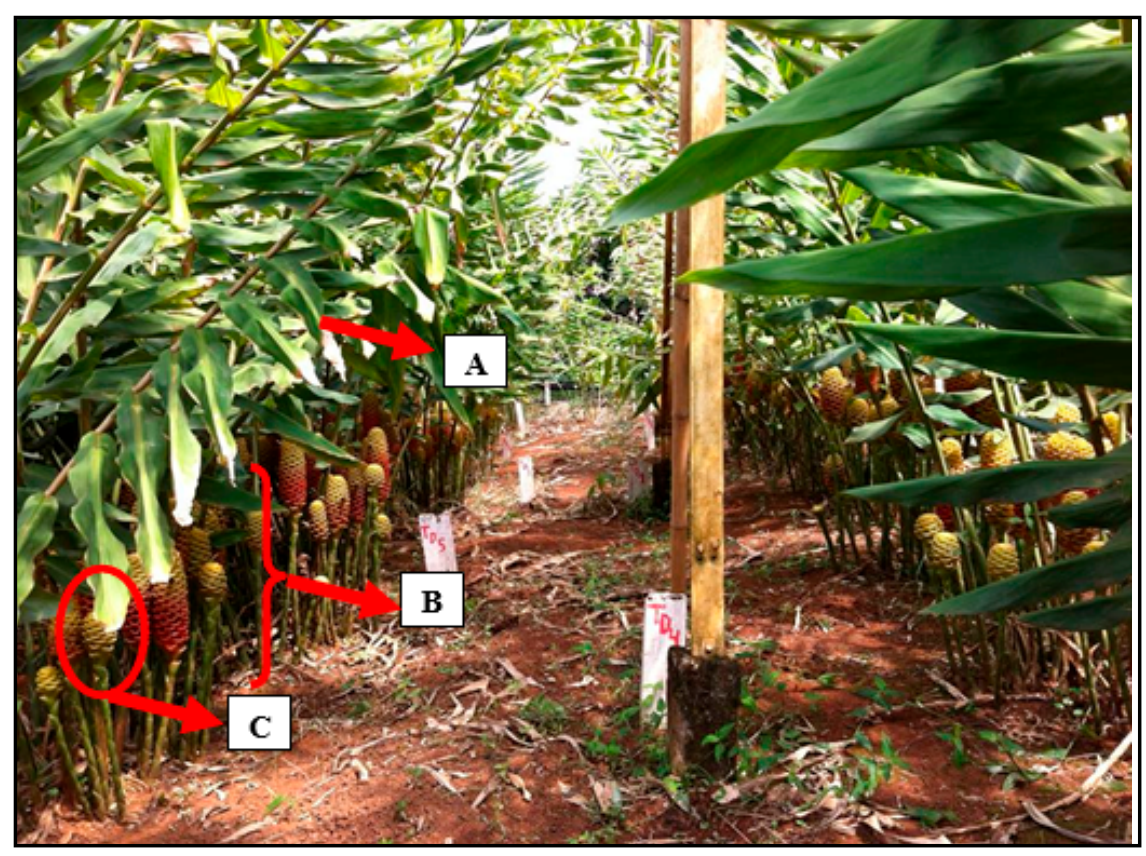

Figure 1. Image of ornamental ginger plants during the experiment: tiller leaves/tussock (vegetative stems) (A), stem (B) is determinded by stem size from the base to the top (inflorescence top) and inflorescence (C). Alfenas, UNIFENAS, 2012-2016. 
redistributed to drains (inflorescences). Nitrogen is related to the most biochemical and physiological processes in plant: respiration, root development and activity, ionic absorption of other nutrients, cell growth and differentiation
(Taiz \& Zeiger, 2017). It is also related to the production of amino acids, which make up the proteins, giving this element structural function; participates in chlorophyll molecule, is part of the nucleic acids and several cellular compounds (Marschner, 2012).

In order to classify commercial flowers/tussock/year, according to Velling-Holambra (2018), at a dose of $400 \mathrm{~kg} \mathrm{ha}^{-1}$ of $\mathrm{N}$, the number of flowers which were discarded (Figure
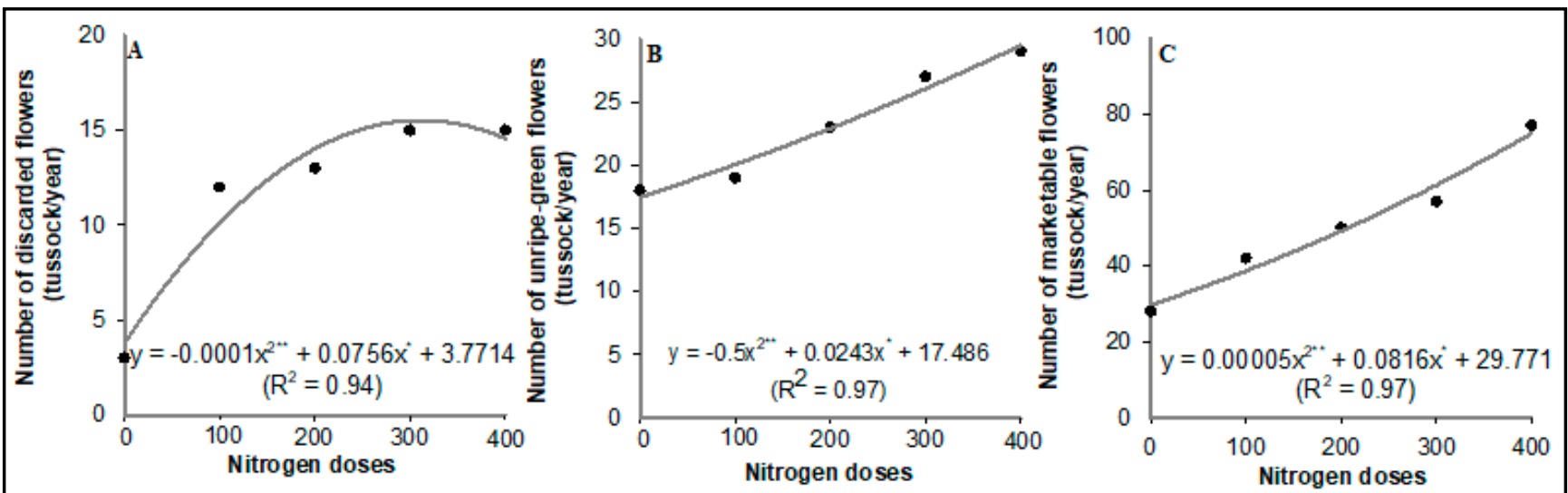

Figure 2. Number of discarded flowers (A), unripe-green (B) and commercial (C) of ornamental ginger tussock/year under different $\mathrm{N}$ doses applied via fertigation in protected environment. Alfenas, UNIFENAS, 2012-2016.

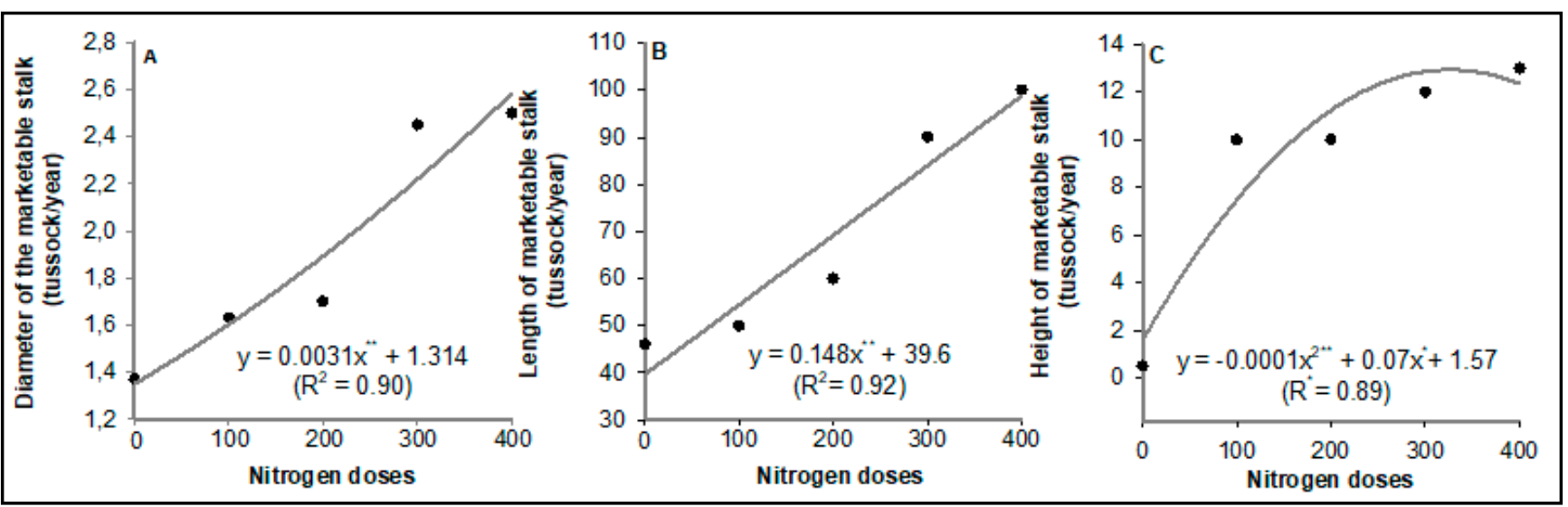

Figure 3. Commercial stem diameter (A), length (B) and height (C) of commercial stem of ornamental ginger flower cultivated under $\mathrm{N}$ doses applied via fertigation. Alfenas, UNIFENAS, 2012-2016.

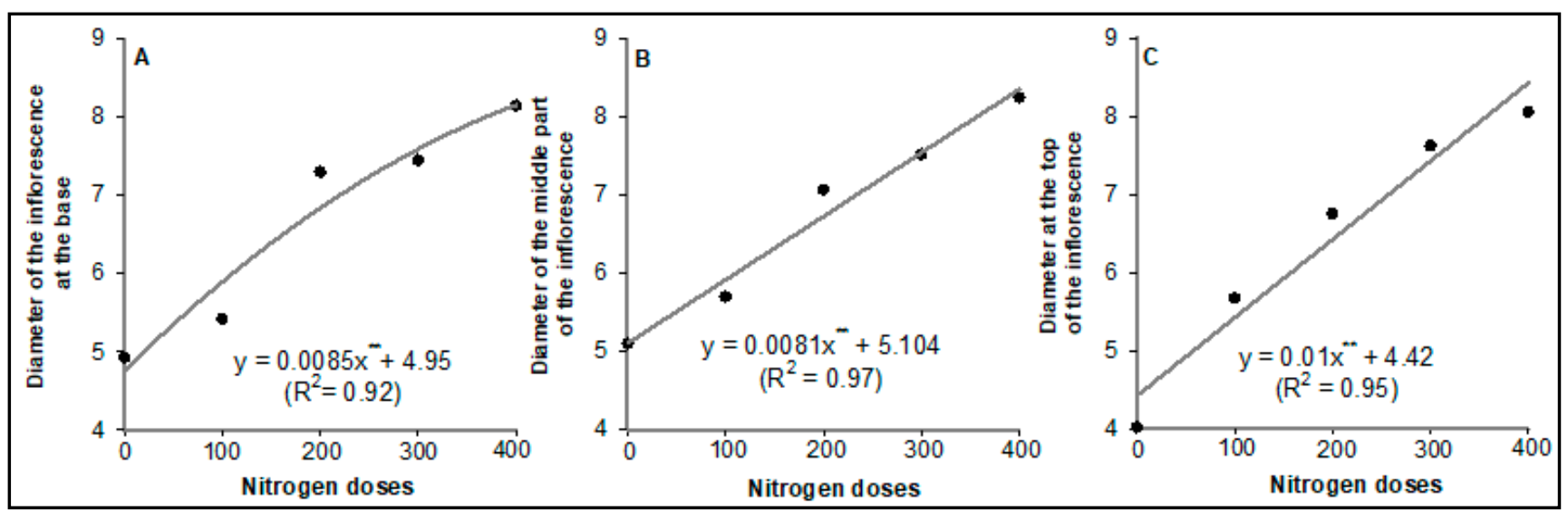

Figure 4. Diameter at the first part (A), the middle (B) and the top (C) of ornamental ginger inflorescence in relation to $\mathrm{N}$ doses applied via fertigation. Alfenas, UNIFENAS, 2012-2016. 


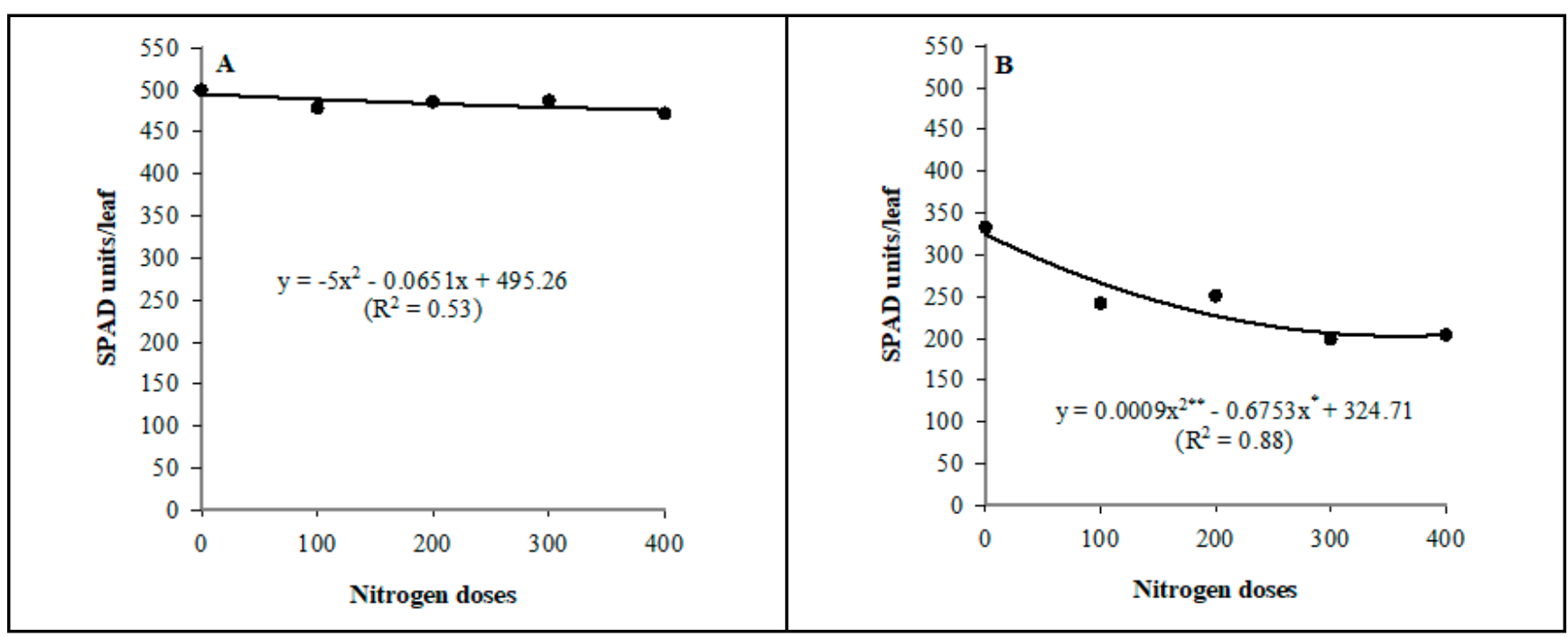

Figure 5. Quantification of SPAD index at the beginning (A) and at the end of the experiment (B) using 30 ornamental ginger leaves, using different $\mathrm{N}$ doses applied via fertigation. Alfenas, UNIFENAS, 2012-2016.

$2 A$ ) increased $400 \%$ (15 flowers), unripe flowers (Figure 2B) 160\% (29 flowers) and commercial flowers (Figure 2C) $260 \%$ (77 flowers). These results are not in agreement with the ones found by Lamas (2002), which concluded that, in ornamental ginger crop the dose of $200 \mathrm{~kg} \mathrm{ha}^{-1} \mathrm{~N}$ provided a production of 100 flowers per year. $\mathrm{N}$ is part of plant protein composition and an increase in its concentration provides greater vegetative development, which favors an increase in production and standardization of flowers. According to Velling-Holambra (2018), the standardization for lot commercialization is established according to the tolerance of serious and minor defects. The producer should eliminate the serious defects before packing flowers.

For diameter, length and height of the commercial stem flower (Figure $3 \mathrm{~A}, \mathrm{~B}$ and $\mathrm{C}$ ) the authors observed that with an increase of $\mathrm{N}$ doses, greater development $(2.7 \mathrm{~cm}, 100 \mathrm{~cm}$ and 13 $\mathrm{cm}$, respectively) was observed. Height of stem and inflorescence is of great importance for commercializing this tropical flower, which is separated into homogeneous lots in relation to standard and quality. Stem length between 90 to $100 \mathrm{~cm}$, observed for 300 and $400 \mathrm{~kg} \mathrm{ha}^{-1}$ of $\mathrm{N}$ doses, is within commercialization standard used by Velling-Holambra (2018). Thus, only the longest stems and inflorescences are commercialized at distribution places, obtaining the best prices. Classification criterion is a tool to unify the communication in all production, producer, wholesaler, retailer and consumer chain. So it is necessary to follow the same criteria in order to determine the product quality. This favors higher transparency in marketing, product valorization, quality improvement, increasing consumption. Tropical flower classified lot should present $95 \%$ uniformity related to length, size and thickness of stem. The bunch of flowers shall be uniform in height and inflorescences. Great differences in stem size and inflorescences will declassify the product. The inflorescences should be upright, proportionate to stems; crook-necked inflorescence are disqualified (Veiling-Holambra, 2018).

For diameter at the base (Figure 4A), the middle (Figure 4B) and the top (Figure 4C) inflorescence, higher values were obtained using dose of $400 \mathrm{~kg} \mathrm{ha}^{-1} \mathrm{~N}$ ( $8.1 \mathrm{~cm}, 8.3 \mathrm{~cm}$ and $13 \mathrm{~cm}$ respectively). This shows that higher applications of $\mathrm{N}$ favor production of longer stems, showing better commercial standard. Ornamental ginger inflorescences can show a diameter of up to $12 \mathrm{~cm}$, starting its development during the warmest months of the year (November to April), according to Lamas (2002).

For green color intensity, estimated through SPAD index (Figure 5A), at the beginning of the experiment, no tendency to increase or decrease was noticed. This result can be related to the fact that the plants are in the initial phenological stage and in adaptation phase, representing slower growth of bulbs, leaves and new sprouts. For green color intensity at the end of the experiment (Figure 5B), the authors noticed a tendency to decrease in relation to an increase of $\mathrm{N}$ doses. This result can be related to higher production of many vegetative stems, and inflorescences, which caused an effect of $\mathrm{N}$ dilution in the crop, due to formation of tussocks, stems and inflorescences. Green color intensity, measured using SPAD, is related to $\mathrm{N}$ concentration in the leaf. Some studies demonstrated that, for some crops, chlorophyll concentration is positively related to leaf $\mathrm{N}$ concentration (Pôrto et al., 2011). This is due to the fact that $70 \%$ of $\mathrm{N}$ contained in the leaves is in the chloroplasts, participating in synthesis and structure of chlorophyll molecules (Marenco \& Lopes, 2005). That is why, the chlorophyll content at the end of vegetative phase has been related to $\mathrm{N}$ nutritional status of several crops (Argenta et al., 2001). However, evaluating application of high fertilizer doses in soil, Marques et al. (2012) did not verify any negative effect on chlorophyll $a$ and $b$ content and on $\mathrm{N}$ concentration in eggplant leaves. The authors concluded that an increase in nitrogen doses up to $400 \mathrm{~kg} \mathrm{ha}^{-1}$ via fertigation produces $77100-\mathrm{cm}$ high commercial flowers/tussock/year, 
favoring commercial production and standardization of ornamental ginger.

\section{ACKNOWLEDGEMENTS}

This research was supported financially by the National Council of Scientific and Technological Development (CNPq/Brazil). For Marques DJ was supported by the productivity grant of the National Council of Scientific and Technological Development (CNPq/Brazil).

\section{REFERENCES}

ARGENTA, G; SILVA, PRF; BARTOLINI, CG. 2001. Clorofila na folha como indicador do nível de nitrogênio em cereais. Ciência Rural 31: 715-722.

ALBUQUERQUE, ESB; NEVES, LJ. 2004. Anatomia foliar de Alpinia zerumbet (Pers.) Burtt \& Smith (Zingiberaceae). Acta Botanica Brasilica 18: 109-121. Available: https://dx.doi. org/10.1590/S0102-33062004000100010

BEZERRA, FC; LOGES, V. 2005. Zingiberaceae. In: TERAO, D; CARVALHO, ACPP; BARROSO, TCSF (eds). Flores tropicais. Brasília: Embrapa Informações Tecnológicas. 225p.

CAMARGO, OA; MONIZ, AC; JORGE, JA; VALADARES, JMAS. 2009. Métodos de análise química, mineralógica e física de solos do Instituto Agronômico de Campinas. Campinas: Instituto Agronômico. $77 \mathrm{p}$. (Boletim técnico, 106).

CUNHA, GR; DALMAGO, GA; ESTEFANEL, V. 1999. Influences on wheat crop in Brazil.
Revista Brasileira de Agrometeorologia 7: 127-138.

EPSTEIN, E; BLOOM, A. 2004. Mineral nutrition of plants. Sunderland: Sinauear Associates. $303 \mathrm{p}$.

FAGERIA, NK. 2014. Nitrogen management in crop production. California: Boca Raton, CRC Press. 320p.

FERREIRA, DF. 2011. Sisvar: a computer statistical analysis system. Ciência e Agrotecnologia 35: 1039-1042.

IBRAFLOR - Instituto Brasileiro de Floricultura 2015. Acessed: February 13, 2018. Mapeamento e quantificação da cadeia de flores e plantas ornamentais do Brasil. Coordenação e organização Neves MF \& Mairun Pinto MJA. São Paulo: OCESP, 2015. Available at: http://www.ibraflor.com/site/ wp-content/uploads/2017/10/diagnosticodo-setor.pdf

LAMAS, AM. 2002. Floricultura tropical: técnicas de cultivo. Recife: SEBRAE-PE. 88p.

LUZ, PB; ALMEIDA, EFA; PAIVA, PDO; RIBEIRO, TR. 2005. Cultivo de flores tropicais. Informe agropecuário 26: 62-72.

MARQUES, DJ; BROETTO, F, LOBATO, AKS; SILVA, EC; CARVALHO, JG; ÁVILA, FW. 2012. Photosynthetic pigments, nitrogen status, and flower behavior in eggplant exposed to different sources and levels of potassium. Scientific Research and Essays 8: 67-74.

MARENCO, RA; LOPES, NF. 2005. Fisiologia Vegetal: fotossintese, respiração, relações hídricas e nutrição mineral. 2. ed. Viçosa: UFV. 439p.

MARSCHNER, P. 2012. Marschner's mineral nutrition of higher plants. 3. ed. New York: Academic Press. 651p.

MOREIRA, FMS; NÓBREGA, RSA; CARVALHO, F; SILVA, K. 2013. Bactérias associativas: fixadoras de nitrogênio atmosférico. In: MOREIRA, FMS; CARES, JE; ZANETTI, R; STÜMER, SL (eds). $O$ ecossistema solo: componentes, relações ecológicas e efeitos na produção vegetal. Lavras: UFLA. 341-350p.

PÔRTO, ML; PUIATTI, M; FONTES, PCR; CECON, PR; ALVES, JC; ARRUDA, JA. 2011. Índice SPAD para o diagnóstico do estado de nitrogênio na cultura da abobrinha. Horticultura Brasileira 29: 311-315.

RAIJ, B; ANDRADE, JC; CANTARELLA, H; QUAGGIO, JA. 2001. Análise química para avaliação da fertilidade de solos tropicais. Campinas: Instituto Agronômico de Campinas. 285p.

SEBRAE. 2015. Flores e plantas ornamentais do Brasil. 2. ed. Unidade de Acesso a Mercados e Serviços Financeiros. 100p.

STEEL, RGD; TORRIE, JH; DICKEY, DA. 2006 Principles and procedures of statistics: a biometrical approach, $3^{\text {rd }}$ ed. Moorpark: Academic Internet Publishers.

VEILING-HOLAMBRA. 2018. Accessed: February 13 2018. Produtos e plantas ornamentais. Available: http://www.veiling. com.br/produtos

TAIZ, L; ZEIGER, E. 2017. Fisiologia vegetal. 6. ed. Porto Alegre: Artmed. 858p.

TERAO, D; CARVALHO, ACPP; BARROSO, TCS. 2005. Flores tropicais. Brasília: Embrapa, Informação Tecnológica. 225p.

WANG, J; NAN, Z; CHRISTENSEN, MJ; ZHANG, X; TIAN, PEI; ZHANG, Z; NIU, X; PENG, GAO, P; TAO, CHEN, T; LIXIA, MA L. 2018. Effect of Epichloë gansuensis endophyte on the nitrogen metabolism, nitrogen use efficiency, and stoichiometry of Achnatherum inebrians under nitrogen limitation Journal of Agricultural and Food Chemistry 66: 4022-4031. Available: https:// dx.doi.org/10.1021/acs.jafc.7b06158

WISNUBROTO, EI; UTOMO, WH; SOELISTYARI, HT. 2017. Biochar as a carrier for nitrogen plant nutrition: The release of nitrogen from biochar enriched with ammonium sulfate and nitrate acid. International Journal of Applied Engineering Research 12: 1035-1042. 